\title{
Training Chaplains and Spiritual Caregivers: The Emergence and Growth of Chaplaincy Programs in Theological Education
}

\author{
Wendy Cadge ${ }^{1} \cdot$ Irene Elizabeth Stroud ${ }^{2}$ - Patricia K. Palmer ${ }^{3} \cdot$ George Fitchett $^{4}$. \\ Trace Haythorn $^{2}$ - Casey Clevenger ${ }^{1}$
}

Published online: 17 June 2020

(C) The Author(s) 2020

\begin{abstract}
This paper describes the history of chaplaincy programs in theological education, the content of their curricula, the goals of the programs as described by faculty, and the programs' approaches to issues of spiritual and religious diversity. It is based on a sample of 21 schools that offer specific chaplaincy education through masters of divinity or masters of arts degrees. We conducted semi-structured interviews with faculty at these schools and reviewed materials from course catalogues and other sources. We found substantial growth in chaplaincy-focused programs in theological schools in the last 20 years as well as the lack of standardization across them that one might expect in a rapidly growing field. The programs mostly developed independent of one another. They have not come to consensus about the skills and competencies chaplains need to do their work and have only engaged in that question across institutions in limited ways. As a group, these programs are also not well connected to clinical chaplaincy training or the day-to-day employment requirements of paid chaplaincy positions. We describe opportunities for collaboration that might strengthen this emerging field and better position it in the changing religious landscape.
\end{abstract}

Keywords Chaplaincy education · Theological schools $\cdot$ Chaplain · Spiritual caregiver

A basic MDiv prepares somebody to serve in the pastorate, and according to ATS [Association of Theological Schools] standards we have to map out those

Wendy Cadge

wcadge@brandeis.edu

1 Department of Sociology, Brandeis University, Waltham, MA, USA

2 Association of Clinical Pastoral Education, Atlanta, GA, USA

3 Emory University, Atlanta, GA, USA

4 Rush University Medical Center, Chicago, IL, USA 
outcomes, and we map them out very carefully so that our MDivs will in fact, on paper at least, equip someone to the standards. Those standards do not include many of the really important functional areas of chaplaincy. Those of us who have gone into chaplaincy, we had to discover how to be successful chaplains. We had to figure it out on our own. And that was kind of a hit-and-miss process.

-William Payne

In the context of well-documented declines in theological school enrollments, specialized education for chaplaincy appears to be an area of growth. Of the 270 Association of Theological Schools (ATS) member schools, candidates, and affiliates, just under 70 offer some type of specialized chaplaincy program. Over a dozen schools in the United States that offer accredited master's degrees but are not affiliated with the ATS also have chaplaincy programs, including Jewish, Muslim, Buddhist, and interfaith institutions. Most of these programs were started in the last 20 years, and new programs continue to emerge. This education for chaplaincy-sometimes called spiritual care-in graduate theological education sits alongside clinical training for chaplains that is primarily offered by educators certified by the ACPE, considered by many to be the standard for spiritual care and education. Interest in clinical pastoral education (CPE) is also growing. Between 2005 and 2015, the number of student units of CPE completed increased by $25 \%$, as described in Fig. 1. Although most CPE centers are not affiliated with theological schools, growing numbers are-since 2002, 12 theological schools in the United States have established their own CPE centers or started hosting satellite centers.

The emergence and growth of education for chaplaincy in theological schools is taking place in the context of several broad changes in American religious life and religious leadership. Although the majority of people in the United States remain Christian, the proportion who identify as having no religious affiliation is growing

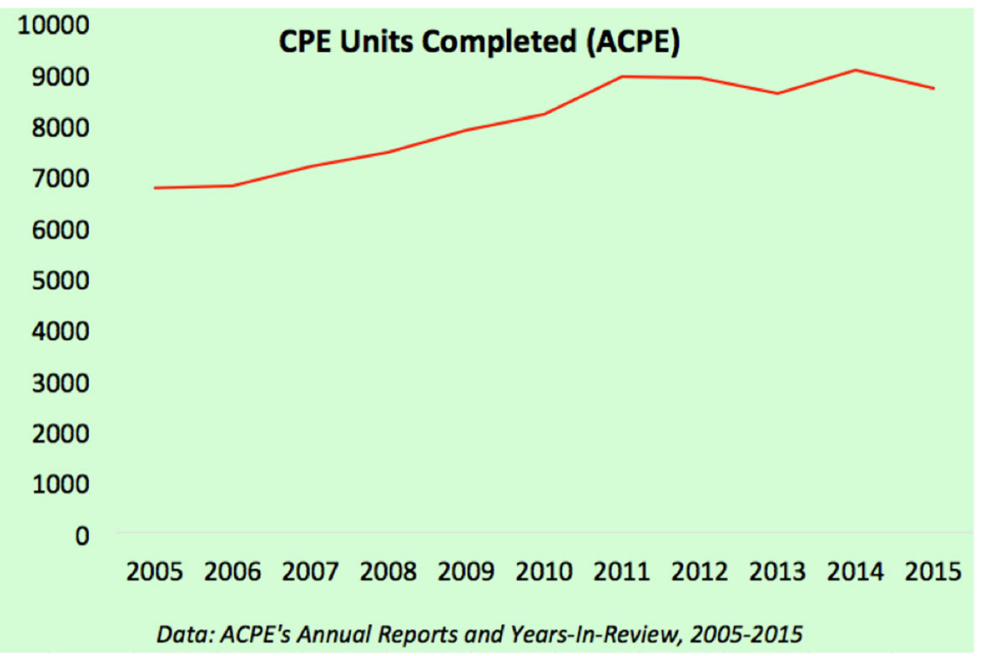

Fig. 1 Number of CPE Units Completed 2005-2015 


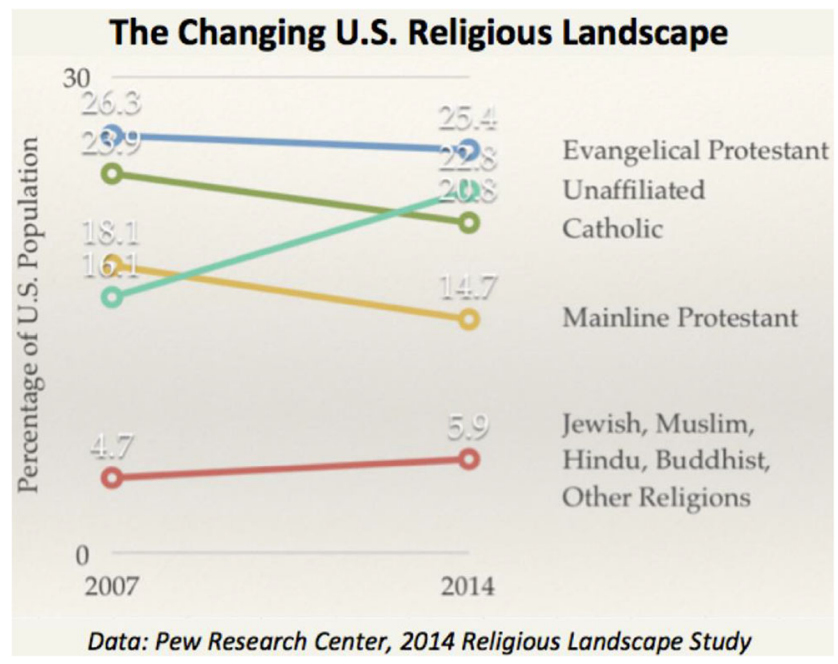

Fig. 2 The Changing U.S. Religious Landscape (Pew Forum 2014), reprinted with permission

rapidly, from $16.1 \%$ to $20.8 \%$ of the population between 2007 and 2014 , as shown in Fig. 2 (Cooperman 2015). The number of clergy working outside of congregations may be on the rise (Schleifer and Cadge 2019). Some studies and media accounts describe clergy working for multiple congregations and/or in multiple occupations, including ones outside of religious organizations, to make ends meet (Chang 2004; Francis et al. 2013; Vaters 2017; Wheeler July 22, 2014). Theological schools are feeling the pinch as enrollments decline. Between 2006 and 2016, the enrollment of students in master of divinity (MDiv) programs at ATS member schools dropped 14\%, as depicted in Fig. 3. Many mainline Protestant schools have closed or merged with others, and others are starting new degree programs and/or offering degrees through different delivery mechanisms in efforts to attract students (Tanner 2017).

Chaplaincy programs emerging in theological schools are responding to all these trends and pressures. Most prepare students to work outside of congregations and with people from a range of religious and spiritual backgrounds, including none, and the presence of these programs may be recruiting new students and helping to bolster enrollments. This paper describes the history of chaplaincy programs in theological education, the content of their curricula, the goals of the programs as described by faculty, and the programs' approaches to issues of spiritual and religious diversity. We focus on a sample of 21 schools that offer specific chaplaincy education through MDiv or master of arts (MA) degrees. We selected these 21 schools purposively after first compiling a list of all graduate theological schools offering chaplaincy tracks or degree programs. We aimed with these 21 to describe the breadth and range of these programs and to begin to outline their varied histories and foci. We conducted semi-structured interviews with faculty who established, administer, and/or teach in these programs, asking about their history, goals, and approach. We combined data from interviews with 


\section{Theological School Full-Time-Equivalent Enrollment, U.S.}

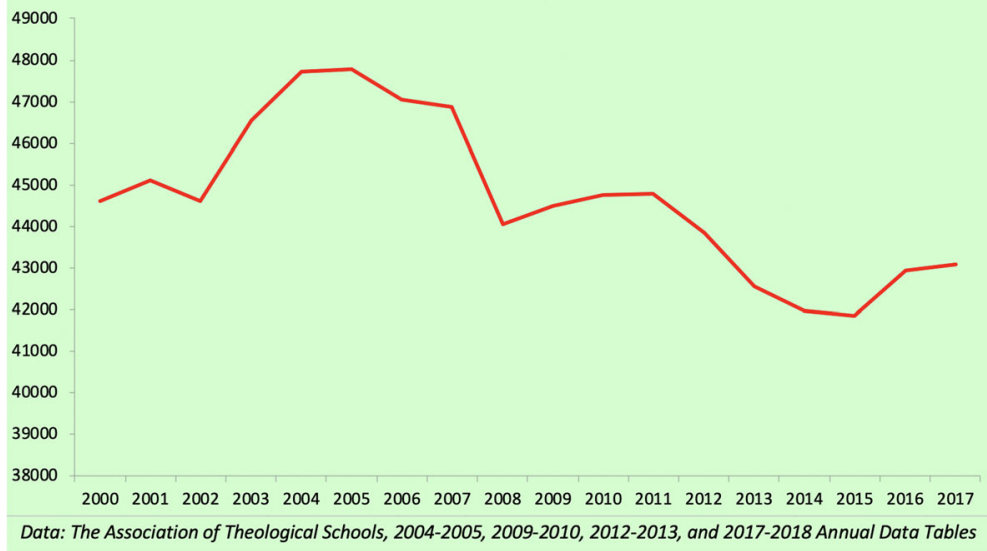

Fig. 3 Theological School Enrollment, 2000-2017

materials from course catalogues and other sources whenever possible to paint a fuller picture of these efforts. ${ }^{1}$

We found substantial growth in chaplaincy-focused programs in theological schools in the last 20 years as well as the lack of standardization across them that one might expect in a rapidly growing field. The programs mostly developed independent of one another. Faculty at these programs have not come to consensus about the skills and competencies chaplains need to do their work and have only engaged in that question across institutions in limited ways. Although there are broad similarities in the knowledge base, skills, and character traits theological educators seek to instill in students, the programs are quite diverse in terms of their histories, curricula, strengths, and vulnerabilities. As a group, these programs are also not well connected to the clinical training most chaplains receive or to the day-to-day employment requirements of paid chaplaincy positions in a range of settings. We describe opportunities for

\footnotetext{
${ }^{1}$ We compiled this sample by first searching the websites of ATS member schools for any type of chaplaincy education program. Then, we performed similar searches of the websites of schools accredited by TRACS (Transnational Association of Christian Colleges and Schools) and AARTS (the Association of Advanced Rabbinical and Talmudic Schools). We also searched the directories of the regional higher education accreditation agencies (the Higher Learning Commission, the Middle States Commission on Higher Education Accreditation, the New England Commission of Higher Education, the Commission on Colleges of the Southern Association of Colleges and Schools, and the Senior College and University Commission of the Western Association of Schools and Colleges) for other institutions that offered graduate-level degree programs for religious leaders, and we performed a similar search of those institutions' websites. This yielded a list of academic chaplaincy programs that may not be all-inclusive but is more comprehensive than any previous list. Because so many schools had chaplaincy programs, it was necessary to select a sample to focus on in this study. A large majority of the schools with chaplaincy programs were Protestant seminaries and divinity schools, so for the sample we chose schools that advertised two or more types of chaplaincy programs (for example, both an MA degree in chaplaincy and a chaplaincy track within an MDiv program) and tried to select roughly equal numbers of mainline and evangelical institutions. We then oversampled schools affiliated with all other religious traditions (Jewish, Muslim, Buddhist, Roman Catholic, and interreligious schools) by including all the ones we could find that offered a chaplaincy program. A few schools were later eliminated from the study either because they chose not to participate in the study, because they were not currently offering a chaplaincy program even though it appeared they were from their institutional websites, or because after multiple attempts by telephone and email we were unable to reach an appropriate person at the school to interview.
} 
collaboration across theological schools and with colleagues in clinical education and employing institutions that might strengthen this emerging field and better position it in the changing religious landscape.

\section{A short history}

In the context of graduate-level theological education, specialized training for the profession of chaplaincy is a new phenomenon. Christian theological seminaries and divinity schools in the United States were established historically to produce educated leaders for churches: pastors of congregations, theologians to articulate the Christian faith and teach future generations of pastors and, to a lesser extent, theologically trained leaders for nonprofit organizations, government, and other areas of public life. Until very recently, few degree-granting theological schools conceived of chaplains as needing anything different from their academic programs than all their other students. In the Christian setting, the MDiv, with its fourfold program of education in biblical studies, theology, history, and the various arts of ministry, was thought to be adequate for chaplains as well. In some sectors where chaplains work, such as the U.S. Armed Forces, the MDiv is accepted as sufficient academic preparation (Stahl 2017; Sullivan 2014).

Some chaplains, particularly those in health care, have long pursued specialized education to supplement their graduate theological degrees. The CPE movement emerged in the mid1920s when Anton Boisen, the chaplain at Worcester State Hospital in Massachusetts, began to experiment with using the mental hospital as a theological laboratory. He invited students to spend their summers in the hospital, serving as ward attendants by day and meeting for theological reflection at night. During the same years, Richard Cabot, often called the "father of medical social work," wrote "A Plea for a Clinical Year for Theological Students" in which he urged theological schools to follow the example of medical education by integrating an internship year into the basic professional degree (Asquith 1992).

Due to the shared vision and energy of Cabot, Boisen, and others, the CPE movement expanded rapidly. Cabot's proposal for integrating a clinical year into theological education was never realized. Instead, CPE developed its own organizations and centers that operated parallel to theological seminaries and divinity schools. Some Protestant denominations came to require or strongly recommend at least one unit of CPE for ordination, and most seminaries came to award academic credit toward the MDiv_ generally the equivalent of one academic course - for a maximum of one unit of CPE. Further units of CPE were often pursued only by specialists in pastoral care: congregational pastors who placed unusual value on their caring and healing functions, pastoral counselors and psychotherapists, and chaplains - especially healthcare chaplains. Until the 1970s, CPE remained an overwhelmingly mainline Protestant educational program, dominated by clergy that skewed White and male and by denominations that required a high level of education for ordination, particularly Presbyterians, Unitarians, Congregationalists, and Methodists. Lutherans developed their own CPE programs and organizations, as did Southern Baptists. Today, not all seminaries require CPE, though most allow students to earn academic credit by taking one unit (Cadge 2012; Eastman 1951; Gerkin 1997; Hall 1992; Holifield 1983; Johnson 1968; Myers-Shirk 2008). One unit of CPE is roughly the equivalent of $100 \mathrm{~h}$ of direct and/or facilitated instruction and $300 \mathrm{~h}$ of experiential practice. 
The oldest specialized chaplaincy program within graduate theological education - as opposed to alongside or subsequent to it - was established in 1988 at Pentecostal Theological Seminary in Cleveland, Tennessee, the flagship school of the Church of God International. ${ }^{2}$ Since then, our evidence suggests accelerating growth, as shown in Fig. 4. In our sample of 21 academic chaplaincy programs, only the one at Pentecostal dates to before 1990. A few in our sample were established in the 1990s, but most started after 2000.

The chaplaincy program at Denver Seminary, which first enrolled students in 1998, is among the oldest and best known in the United States. Its founder, Jan McCormack, was a military chaplain for twenty years and was working on her doctor of ministry degree at the seminary while serving as the senior chaplain at Buckley Guard Base (now Buckley Air Force Base) when administrators approached her about developing a way for students to specialize in chaplaincy. From her military experience, McCormack knew that many people, particularly young people, were willing to trust chaplains even if they didn't trust organized religion or clergy in general. That knowledge motivated her to build a program that now includes multiple degree options and a fully accredited CPE center. McCormack described chaplaincy as fundamentally different from congregational ministry, saying, "We chaplains don't wait for people to come to us. We go to them. And we're typically working in someone else's work center. .. so in many ways we're all workplace chaplains. It's a whole different mindset for people to think that it isn't just taking what I do in the church, putting a new title on it, and doing it somewhere else." Denver Seminary graduates now work as chaplains in settings ranging from the military and health care to NASCAR racetracks. McCormack's book, The Work of the Chaplain, is used as a textbook in chaplaincy programs across the country, and other chaplaincy programs have used hers as a model (Paget and McCormack 2006).

Across the 21 schools we examined, we identified five major patterns in how academic chaplaincy programs emerged: a military chaplaincy pattern, a pastoral counseling pattern, a minority religion pattern, a CPE pattern, and an interfaith pattern. The military chaplaincy pattern seems most common in evangelical seminaries such as Pentecostal, Denver, Ashland Theological Seminary, and Columbia Biblical Seminary, but we also see it at the Seminary of the Southwest, an Episcopal school, and we see a variation on the theme at Boston University School of Theology, which is United Methodist. In this pattern, military chaplains themselves provide the energy and professional expertise for a new academic program. The programs at Denver, Ashland, Columbia Biblical, and Seminary of the Southwest are all directed by career military chaplains who retired from service with distinguished records. Like many who retire from the military, they retired at a relatively early age, which made it possible for them to pursue ambitious, long-term projects subsequent to their military service.

Variations on McCormack's story were repeated in other interviews. David Scheider, the founding director of the chaplaincy program at Seminary of the Southwest, was an Army

\footnotetext{
${ }^{2}$ The Church of God does not require a master's degree for ordination, and Pentecostal's degree programs thus serve not as academic gateways for students first contemplating a call to ministry but rather as advancement programs for persons the church has already identified as leaders. For Church of God pastors, the academic and training requirements for professional chaplaincy careers are much steeper than those for ordination, and interest in such careers often drives interest in the MDiv. In fact, according to Oliver McMahon, professor of clinical mental health counseling and the current director of the chaplaincy program, from earliest days the seminary's MDiv was envisioned as a path to professional chaplaincy in health care and the armed forces. Pentecostal offers several levels of chaplaincy training, from a one-week intensive course for persons interested in volunteering as chaplains with their local police or fire department or a disaster response team to an MDiv with a chaplaincy focus that includes courses in trauma and crisis counseling, world religions, the theology of suffering, and extensive fieldwork.
} 


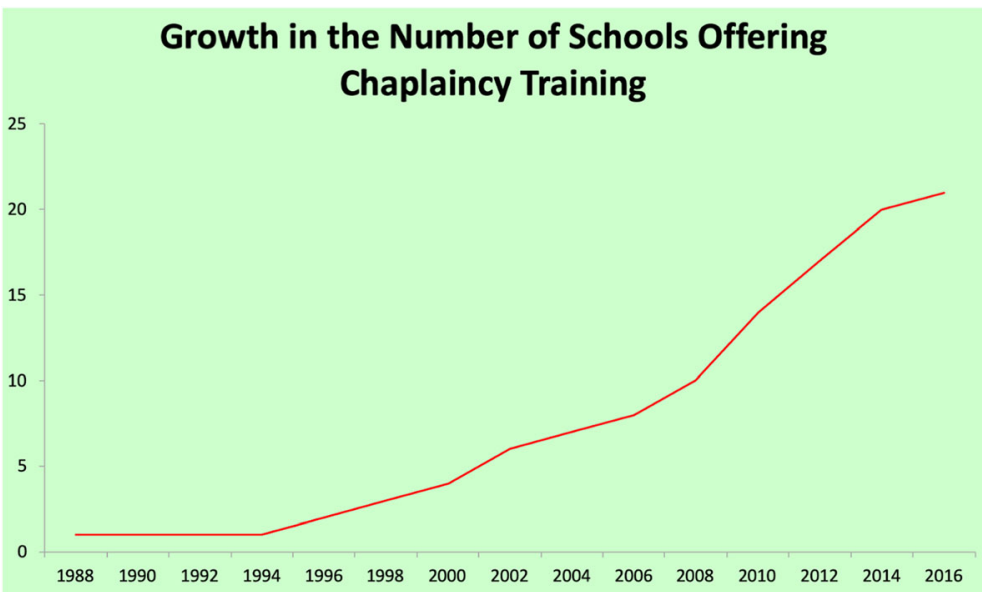

Fig. 4. Growth in Chaplaincy Training Programs in Theological Education 1988-2016, based on our sample of 21 Schools

chaplain for 25 years. William Payne, who designed and directs the program at Ashland, was a Navy chaplain whose military career included serving at one point as deputy chaplain for all of Europe and, later on, all of Iraq. Michael Langston, who created the program at Columbia Biblical, retired from a Navy career that included a tour as the commanding officer of the Navy Chaplain School and executive director of the Armed Forces Chaplaincy Center as well as responsibilities in military diplomacy that included engaging religious leaders in Iraq and Afghanistan and mentoring some of Hamid Karzai's senior cabinet staff in religious leader engagement. It should come as no surprise that seminary administrators have seen these retired military chaplains as resources and looked to them to build programs. The retired chaplains, in turn, were motivated to design strong programs as a result of their military experience. For McCormack, the motivation came from her sense that chaplains inspire trust. Payne was moved by the shortcomings of the chaplains he supervised in the Navy; they were "woefully unprepared," he says, to serve in a pluralistic context. The military chaplaincy pattern also helps explain the emergence of the chaplaincy track at Boston University, where Shelly Rambo, a theologian with a research interest in trauma, noticed the passion and focus of military chaplains who came to Boston University to pursue advanced theological training between deployments. "There was one year where I had several chaplains, and they made a very big impact on me," she says. They had come to Boston University in particular for its certificate program in Religion and Conflict Transformation. Their presence made Rambo think about what else the university could offer military chaplains. ${ }^{3}$

The second pattern of chaplaincy programs, that of emerging out of pastoral counseling, is most common in mainline Protestant schools with a robust tradition of pastoral theology, such as Brite Divinity School and Iliff School of Theology. It is also present at Nazarene Theological Seminary, which is more evangelical in character. In this pattern, a chaplaincy program develops under the guidance of a senior faculty member in the field of pastoral counseling or

\footnotetext{
${ }^{3}$ The financial impact of military investment in higher education and professional advancement for its chaplains can hardly be overestimated. The Boston University students who inspired Rambo were able to be there because the government paid for them to obtain an additional year of schooling to help prepare them for more significant responsibilities. Several leaders of chaplaincy education programs received help from the U.S. Army or Navy in obtaining their doctorates or other advanced degrees.
} 
pastoral theology, often as a gradual shift in emphasis from counseling to chaplaincy within a program. This shift is evident in the work of Joretta Marshall at Brite, who has seen the focus of her program switch from counseling to pastoral care in response to the evolution of licensing requirements (most states no longer offer licensure for pastoral counseling but instead require a license outside that field). Marshall says, "You can get licensed in Kentucky, for example. In Tennessee. And I think in North Carolina, still, as a pastoral counselor. But everybody else mostly has to do LPC [Licensed Professional Counselor] tracks to get licensure or an MSW [master of social work] or have some other kind of clinical degree." Although the program at Brite is now oriented toward pastoral care, students interested in pastoral counseling can pursue a dual track in collaboration with Texas Christian University's School of Social Work to earn an MSW along with their theological degree.

The teaching focus at some of the schools in this group, such as Iliff, also reflects the shift away from counseling and towards spiritual care and chaplaincy. Carrie Doehring says, "I'm trained both as a therapist and a pastor, but my writing and teaching has really focused on spiritual care, both [in] congregations and then intercultural spiritual care in multifaith settings." This reflects Iliff's commitment to preparing students for chaplaincy positions. Echoes of Judith Schwanz's background in counseling may remain in the chaplaincy certificate program at Nazarene, which requires Counseling for Grief and Loss as one of two key courses; nevertheless, the program provides certification of specialty training in chaplaincy rather than counseling. Many of these guiding faculty members have many years of professional counseling experience. As a group, these leaders are responding to changes in licensing and reimbursement practice that make it more difficult to make a living as a pastoral counselor - and perhaps easier to make a living as a chaplain - than in the past.

A third way chaplaincy training programs emerge in theological schools stems from attention to minority religious groups. This pattern is common in schools that serve students from religious groups with small but growing numbers in the U.S. population and limited institutional presence. Islamic programs such as those at Hartford Seminary and Bayan Claremont, recently affiliated with Chicago Theological Seminary, and Buddhist programs such as those at Naropa University and University of the West fall into this group. What is unique about these programs is that a primary reason they offer a master degree in the first place is to open up pathways into professional chaplaincy for their constituents. In Islam, for example, the role of the congregational leader or imam requires specific training and knowledge but not the academic master's degree that would qualify a clergyperson for service as a chaplain in, for example, the armed forces (Jalalzai 2016). Buddhism has highly developed monastic traditions and a system of passing down wisdom through teaching lineages, but it does not have the kind of ordained or licensed leadership historically required to work in the military or federal prisons as a chaplain (Seager 1999).

Training in chaplaincy and a degree (either an MDiv or an MA) grants Muslim and Buddhist chaplaincy students legitimacy in civil society and qualifies them for professional religious service. Hartford, Bayan, Naropa, and University of the West all have graduates serving as chaplains in the armed forces - and without the degrees these schools make available, it would be very difficult for any Muslims or Buddhists to obtain these positions. Although Loyola University Chicago (Catholic) does not represent a minority religion, its chaplaincy program developed to address some of these same limitations, in particular to provide training to Catholic women religious who otherwise had limited avenues to enter leadership positions in ministry. The Jewish theological schools in our sample do not fall 
within this minority religion pattern because the academic training to become a rabbi meets the requirements for certification as a chaplain.

In addition to the military, pastoral counseling, and minority religion approaches, some theological schools began to offer training in chaplaincy through CPE and specifically the wish to establish their own CPE program to prepare students for chaplaincy alongside academic degree programs. The chaplaincy programs at San Francisco Theological Seminary and Eastern Mennonite Seminary, two Protestant schools, and at the Jewish Theological Seminary of America and the Academy for Jewish Religion, California, two Jewish schools, were founded on this pattern. Of these, CPE is most integrated in the Academy, which has the explicit goal of preparing students for certification. The Academy is also unusual in that credit is not offered for CPE independently but for classwork that is integrated with the CPE experience. Rochelle Robbins explains:

At the time I stepped in, doing CPE itself, we began to create, I think, a very unique program. . . I I wanted to integrate the academics with the clinical training but not give credit. Their transcripts do not say clinical pastoral education. They meet the requirement for clinical pastoral education, but the credits are in things like, this year ... [the] first semester ... was spiritual assessment and now we're in theological reflection. . . . I really push them in the realm to demonstrate capacities as it applies to the learning outcomes and as it applies to questions that are going to be asked of them for certification.

At the other end of the spectrum, Kenton Derstine at Eastern Mennonite, which locates itself in the Anabaptist theological tradition, offers CPE out of a belief that it is useful for all ministerial vocations as well as serves as preparation for those students pursuing chaplaincy. Although Denver also has an in-house CPE center, the military experience of Jan McCormack served as the basis for the chaplaincy program there; the CPE program was added later.

The final way we saw chaplaincy programs emerging in theological schools is out of an intentional focus on interreligious or interfaith studies. Both of the programs we examined that followed this approach are mainline Protestant. The program at Claremont School of Theology initiated an interfaith program with Christian, Jewish, and Muslim partners, as well as Buddhist and Hindu affiliates. The consortium was later disbanded for funding reasons; however, cross-enrollment agreements are still in place with Bayan, the Academy of Jewish Religion, and University of the West. As an example of Claremont's commitment to interfaith learning, all MDiv students are required to take a class titled Interreligious Dialogue and Leadership, which is co-taught by professors from Muslim, Christian, and Jewish faith traditions. "Sometimes there's a Buddhist thrown into the mix," Duane Bidwell told us in an interview. The Starr King School for the Ministry is the other location with an interfaith focus. In partnership with The Chaplaincy Institute, which provides an ordination track for people without a denominational pathway, Starr King serves students with a wide range of theological commitments. Christopher Schelin describes Starr King as "a school with a key component of its identity being this multireligious positioning. And so, apart from our Unitarian Universalist students, we have a number of students who are dissenters within their particular faith traditions or they are more eclectic or independent in their religious or spiritual orientation." Starr King offers an MDiv grounded in this faith diversity and, in partnership with The Chaplaincy Institute, equips even the most theologically eclectic students to meet the requirements for chaplaincy certification. 


\section{Chaplaincy curricula in theological schools}

The chaplaincy-related programs we learned about in theological schools and seminaries are diverse in form and content. They include short-term training courses for the general public, certificate programs, MDiv degrees with a chaplaincy focus, MA degrees in chaplaincy, doctor of ministry degrees with a chaplaincy focus, and various combinations of the above. Some theological schools house their own CPE centers accredited by ACPE, while others partner with CPE centers in their cities and states. In the United States and Canada, we identified about 80 theological schools that offer formal curricula in chaplaincy, as shown in Fig. 5. We excluded from this count schools that only offered courses in chaplaincy but not a program. The largest number of schools offer an MDiv degree with a chaplaincy specialization. Growing numbers offer an MA degree in chaplaincy. Small numbers offer certificate programs and/or a DMin with a chaplaincy focus. Nationally, we identified 12 CPE programs housed within theological schools.

These broad patterns were replicated in our sample of 21 schools, as illustrated in Fig. 6 and Table 1. We also note the overwhelming majority of Protestant affiliations of the schools offering this training, both in our sample and nationally, as shown in Figs. 7 and 8. Sixteen schools in our sample offer a chaplaincy specialization in the context of a rabbinical school or MDiv program requiring 72 semester hours of coursework or more. The simplest of these programs do little more than introduce students to the profession of chaplaincy and steer them toward existing courses in the curriculum that are thought to be most useful to chaplains. For example, at Nazarene, MDiv students who wish to get a "certificate in chaplaincy ministry" are required to take two three-credit courses, Introduction to Chaplaincy and Counseling for Grief and Loss, and to use CPE for their field experience. At Boston University, Rambo points out that the chaplaincy track has involved no actual new courses so far; instead, it consists of tweaks to existing distribution requirements. For example, all MDiv students must take two courses in an area called Texts and Traditions, but chaplaincy students must choose a course in religions/interreligious dialogue/ecumenism for at least one of those.

Some of the other MDiv programs with chaplaincy concentrations require a longer list of courses, typically a combination of required courses and electives. At Brite, for example, students pursuing an MDiv with a certificate in military chaplaincy must complete a course

\section{Number of Theological Schools Offering Various Degrees}

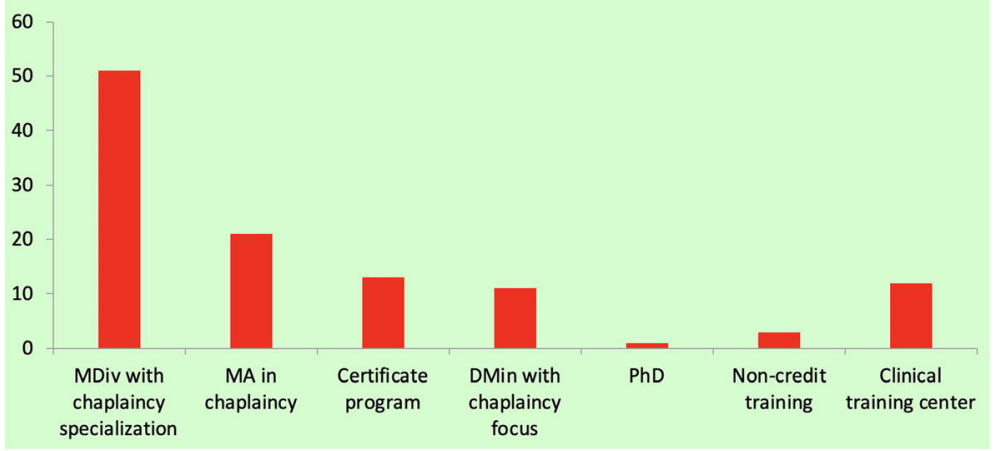

Fig. 5 Degrees Granted by Chaplaincy Programs in Theological Schools, $N=79$ 


\section{Number of Theological Schools Offering Degrees Related to Chaplaincy}

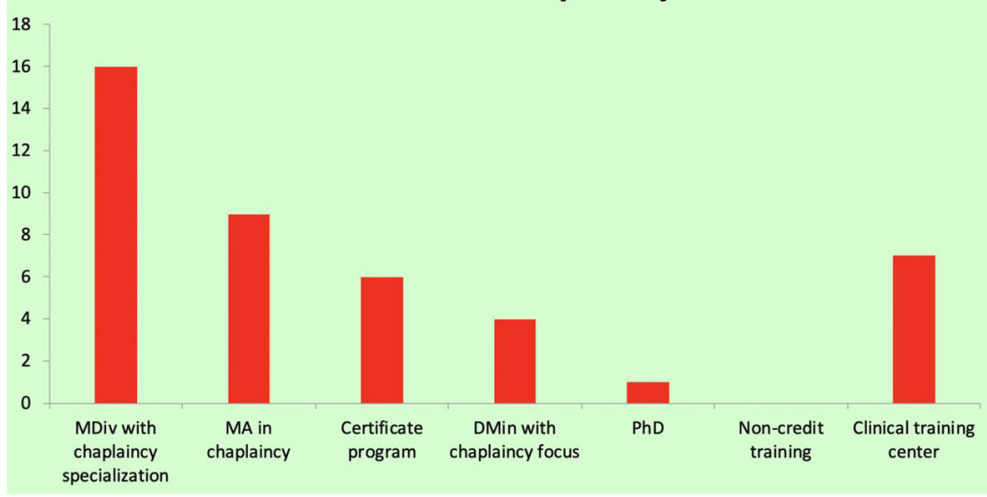

Fig. 6. Degrees Granted by Chaplaincy Programs in Theological Schools in Our Sample, $N=21$

titled The Ministry of Pastoral Care as well as three hours of coursework in military chaplaincy and nine additional courses in pastoral care or courses related to war and peace (their chaplaincy program has a military focus). Students at Denver take a course titled Issues in Counseling Ministries and electives from courses with titles such as Religious Pluralism, The Many Faces of Chaplaincy, Community-Based Clinical Pastoral Education, and Crisis Counseling.

The Muslim and Buddhist programs have tried to rework the MDiv from a Muslim or Buddhist perspective. Bayan offers a 72-h MDiv in Islamic chaplaincy. Claremont, in partnership with Bayan, has an Islamic chaplaincy track in their MDiv that, according to their bulletin, "presupposes that men and women can exercise responsible leadership only when they combine an intimate knowledge of their own traditions, appreciation of other forms of spiritual practice and insight, a deep engagement with today's social and political realities, and strong dialogical and critical thinking skills." Coursework covers sacred texts, the history of particular religious traditions, theology and teaching, and religious and/or faith-based ethics in addition to CPE. Students in the Islamic chaplaincy track also must demonstrate intermediate proficiency in classical Arabic.

Naropa and University of the West have reworked the MDiv from a Buddhist perspective and aim to prepare graduates to work in chaplaincy and other fields from a Buddhist foundation. "The Master of Divinity degree prepares students for professional work in the fields of pastoral care, chaplaincy, community development and dharma teaching," the Naropa Bulletin explains, describing interfaith pastoral care as "the ability to serve the spiritual and human needs of a diverse community in ministerial/chaplaincy roles while embodying the principles and practices of one's primary tradition." Requirements include courses in Buddhism, contemplative practice, field education (with CPE as an option), and other areas. At University of the West, the MDiv in Buddhist chaplaincy incorporates the requirements of the Association of Professional Chaplains, which certifies many chaplains, by offering 72 semester hours that cover the nine topics in which they require training. Forty-five of the required semester hours are in core areas and 27 in electives, which include 6 in comparative religions, 3 in religious education, 6 in religious history, 6 in sacred literature, and 6 in theology/ philosophy. Spiritual formation is emphasized throughout this curriculum, as indicated by the 
Table 1 Basic Requirements of Chaplaincy-Focused Academic Programs in Our Sample, N=21

\begin{tabular}{|c|c|c|c|c|}
\hline School & Program & $\begin{array}{l}\text { Required } \\
\text { Chaplaincy } \\
\text { Coursework } \\
\text { Hours }\end{array}$ & $\begin{array}{l}\text { Total } \\
\text { Degree } \\
\text { Hours }\end{array}$ & $\begin{array}{l}\text { Required } \\
\text { Units of } \\
\text { CPE }\end{array}$ \\
\hline $\begin{array}{l}\text { Academy for Jewish } \\
\text { Religion, California }\end{array}$ & $\begin{array}{l}\text { Master of Jewish Studies with Chaplaincy } \\
\text { School }\end{array}$ & 12 & 72 & 2 \\
\hline \multirow{2}{*}{$\begin{array}{l}\text { Ashland Theological } \\
\text { Seminary }\end{array}$} & MDiv (Chaplaincy) & 27 & 80 & 1 \\
\hline & DMin Chaplaincy Track & 3 courses & 80 & \\
\hline \multirow[t]{2}{*}{ Bayan Claremont } & MDiv in Islamic Chaplaincy & & 72 & \\
\hline & Certificate in Islamic Chaplaincy & 24 & & \\
\hline \multirow[t]{3}{*}{ Brite Divinity School } & MDiv w/ Certificate in Military Chaplaincy & 15 & 81 & \\
\hline & $\begin{array}{l}\text { MA in Theology and Ministry w/ Certificate } \\
\text { in Military Chaplaincy }\end{array}$ & 15 & 48 & \\
\hline & MTS w/ Certificate in Military Chaplaincy & 15 & 49 & \\
\hline Boston University & MDiv with Chaplaincy Track & & 73 & \\
\hline The Chaplaincy Institute & Interfaith Studies Certificate & 21 & & \\
\hline \multirow{4}{*}{$\begin{array}{l}\text { Claremont School of } \\
\text { Theology }\end{array}$} & MDiv Interfaith Chaplaincy Track & 21 & 72 & \\
\hline & MDiv Islamic Chaplaincy Track & 18 & 72 & \\
\hline & $\begin{array}{l}\mathrm{PhD} \text { in Practical Theology, Spiritual Care, } \\
\text { and Counseling with Emphasis in } \\
\text { Clinical Spiritual Care }\end{array}$ & 8 & 48 & 3 \\
\hline & Certificate in Islamic Chaplaincy & 24 & & \\
\hline Columbia Biblical & MA in Chaplaincy & & $36-48^{\mathrm{d}}$ & \\
\hline Seminary of Columbia & MDiv with Chaplaincy Concentration & 18 & 78 & \\
\hline International University & DMin with Chaplaincy Concentration & 18 & 30 & \\
\hline \multirow[t]{2}{*}{ Denver Seminary } & MDiv with Concentration in Chaplaincy & 19 & 78 & 1 \\
\hline & Certificate in Chaplaincy & 15 & & 1 \\
\hline $\begin{array}{l}\text { Eastern Mennonite } \\
\text { Seminary }\end{array}$ & MDiv with focus in Specialized Ministry & 28 & 81 & \\
\hline Hartford Seminary & $\begin{array}{l}\text { MA in Religious Studies with Graduate } \\
\text { Certificate in Islamic Chaplaincy }\end{array}$ & 24 & 72 & 1 \\
\hline \multirow[t]{4}{*}{ Iliff School of Theology } & MA in Pastoral and Spiritual Care & & $80^{\mathrm{b}, \mathrm{c}}$ & 1 \\
\hline & $\begin{array}{l}\text { MDiv Spiritual Care and Chaplaincy } \\
\text { Concentration }\end{array}$ & & $120^{\mathrm{b}}$ & \\
\hline & $\begin{array}{l}\text { MTS Spiritual Care and Chaplaincy } \\
\text { Concentration }\end{array}$ & $16^{\mathrm{b}}$ & $72^{b}$ & \\
\hline & $\begin{array}{l}\text { Certificates for Degree and Non-Degree } \\
\text { Students }\end{array}$ & $16^{\mathrm{b}}$ & & \\
\hline $\begin{array}{l}\text { Jewish Theological } \\
\text { Seminary of America }\end{array}$ & Certificate in Pastoral Care and Counseling & $9-12$ & & 2 \\
\hline $\begin{array}{l}\text { Loyola University Chicago } \\
\text { - Institute of Pastoral } \\
\text { Studies }\end{array}$ & $\begin{array}{l}\text { MA in Pastoral Studies with Health Care } \\
\text { Chaplaincy Concentration }\end{array}$ & & 36 & 4 \\
\hline Naropa University & MDiv & & 72 & 1 \\
\hline $\begin{array}{l}\text { Nazarene Theological } \\
\text { Seminary }\end{array}$ & $\begin{array}{l}\text { Certificate in Chaplaincy Ministry (for } \\
\text { MDiv Students) }\end{array}$ & 12 & 76 & \\
\hline $\begin{array}{l}\text { Pentecostal Theological } \\
\text { Seminary }\end{array}$ & MDiv Concentration in Chaplaincy & 12 & $74-80$ & 1 \\
\hline \multirow[t]{2}{*}{$\begin{array}{l}\text { San Francisco Theological } \\
\text { Seminary }\end{array}$} & $\begin{array}{l}\text { MDiv with Chaplaincy and \& Pastoral Care } \\
\text { Specialization }\end{array}$ & & 72 & \\
\hline & $\begin{array}{l}\text { DMin with Chaplaincy/Spiritual Care Re- } \\
\text { search Literacy Concentration }\end{array}$ & 3 courses & 18 & \\
\hline \multirow[t]{2}{*}{ Seminary of the Southwest } & $\begin{array}{l}\text { MA in Spiritual Formation with a Health } \\
\text { Care Chaplaincy Track }\end{array}$ & 15 & 48 & 1 \\
\hline & $\begin{array}{l}\text { MDiv with Military, Health Care, or School } \\
\text { Chaplaincy Concentration }\end{array}$ & 16 & 90 & $1-2$ \\
\hline
\end{tabular}


Table 1 (continued)

\begin{tabular}{|c|c|c|c|c|}
\hline School & Program & $\begin{array}{l}\text { Required } \\
\text { Chaplaincy } \\
\text { Coursework } \\
\text { Hours }\end{array}$ & $\begin{array}{l}\text { Total } \\
\text { Degree } \\
\text { Hours }\end{array}$ & $\begin{array}{l}\text { Required } \\
\text { Units of } \\
\text { CPE }\end{array}$ \\
\hline \multirow{2}{*}{$\begin{array}{l}\text { Starr King School for the } \\
\text { Ministry, Joint Program } \\
\text { for Interfaith Chaplaincy }\end{array}$} & $\begin{array}{l}\text { MDiv, with Interfaith Studies Certificate } \\
\text { from The Chaplaincy Institute }\end{array}$ & 18 & \multirow[t]{2}{*}{90} & \\
\hline & $\begin{array}{l}\text { MA in Social Change, with Interfaith } \\
\text { Studies Certificate from The Chaplaincy } \\
\text { Institute }\end{array}$ & 18 & & \\
\hline \multirow[t]{2}{*}{ University of the West } & MDiv in Buddhist Chaplaincy & 72 & & \\
\hline & Doctor of Buddhist Ministry & 63 & & \\
\hline
\end{tabular}

$\mathrm{CPE}=$ clinical pastoral education; DMin = doctor of ministry; $\mathrm{MA}=$ master of arts; MDiv = master of divinity; MTS $=$ master of theological studies; $\mathrm{PhD}=$ doctor of philosophy.

a This table includes total semester credit hours for required courses in a chaplaincy concentration, certificate, or focus and semester credit hours for the degree program of which chaplaincy hours are a part; programs include only those with "chaplaincy" or "spiritual care" in their name

${ }^{\mathrm{b}}$ Quarter hours

c 40 quarter hours if the student already has an MDiv

d Program course load depends on the student's academic background

first sentence of the learning objectives, which reads, "Spiritual formation in Buddhist chaplaincy is seen as the development of ethics, contemplative practice, and wisdom."

As a group, the MDiv programs with chaplaincy specializations or certificates continue to meet the accreditation requirements of the MDiv while aiming to include the education that faculty at these schools believe students need to be effective chaplains. What, exactly, that education consists of varies, however, as does the sense faculty have of what is required to be an effective chaplain. Some faculty emphasize the centrality of self-reflection in the process of

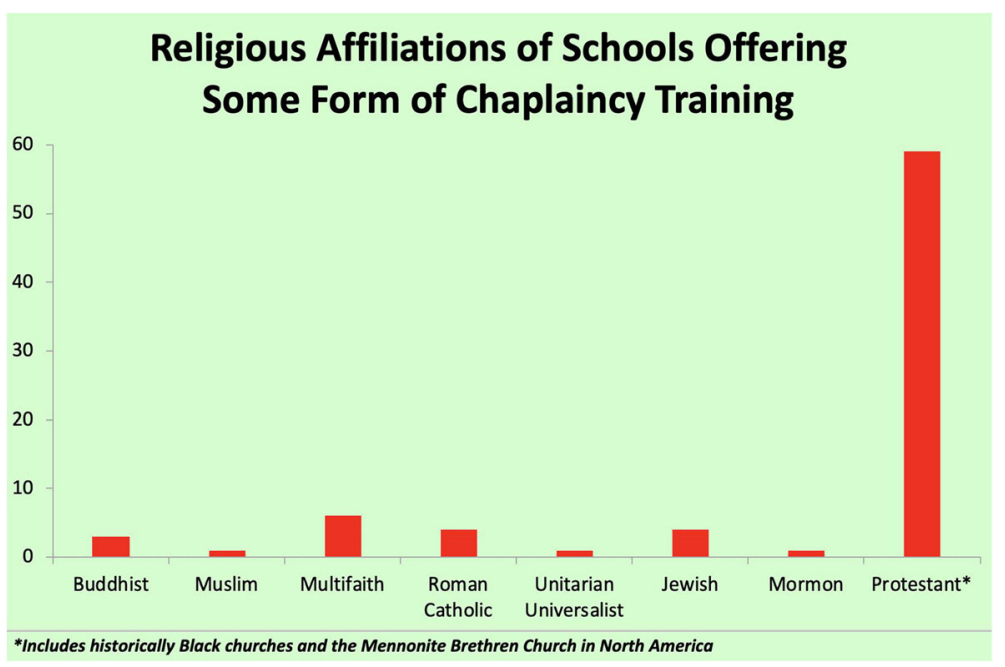

Fig. 7 Religious Affiliation of U.S. Schools Offering Chaplaincy Training, N =79 


\section{Religious Affiliations of Schools Offering Some Form of Chaplaincy Training}

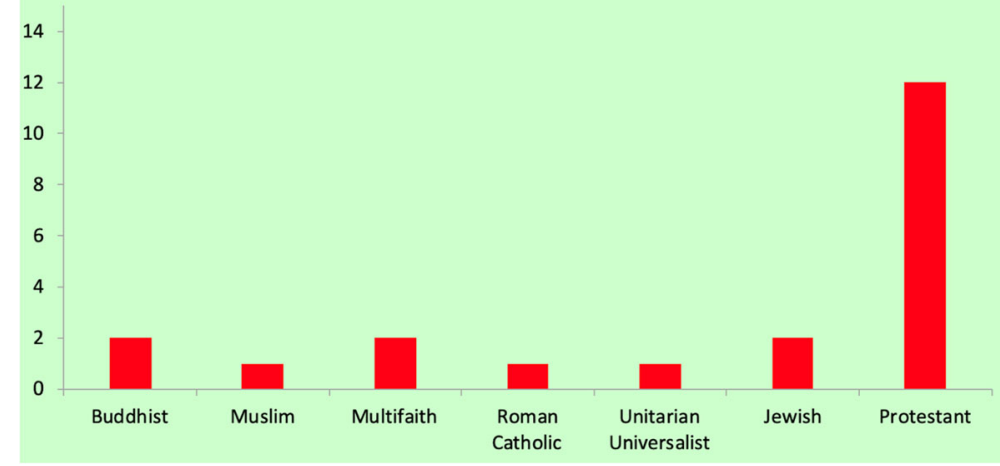

Fig. 8 Religious Affiliation of the Schools in Our Sample Offering Chaplaincy Training, N=21

training to be a chaplain, while others emphasize experience with ritual, language, and ethics as central to the training. Some of this variation may be explained by the settings students in specific programs are training to work in, such as the military or health care, but more of it likely relates to the background of the faculty and their own professional development and experience with chaplaincy. As in many emerging fields, the curricula of MDiv programs in chaplaincy are varied, and leaders have not yet come to a common understanding about what someone who gets an MDiv in chaplaincy should know and the extent to which the answer to that question should be standard across schools and universities.

In addition to the MDiv degree, nine schools in our sample offer some kind of an MA degree in chaplaincy. Loyola offers a master of arts in pastoral studies with a healthcare chaplaincy concentration. The 36-h program aims to prepare students to be board-certified chaplains through the National Association of Catholic Chaplains. The degree requires eight core courses as well as three healthcare-related electives, four units of CPE, two workshops, and a healthcare integration project. Columbia Biblical Seminary offers a residential or fully online 36- to 48-h (depending on a student's academic background) MA in chaplaincy that, as their bulletin explains, "provides students with specialized skills to perform the pastoral, caregiver, emotional, and spiritual support roles of a chaplain." The MA in chaplaincy and pastoral care at the Seminary of the Southwest requires students to take 12 of their 72 credits in a core curriculum they share with spiritual direction and counseling students, 45 in courses designed especially for chaplaincy, and 15 in electives. Some of the MA programs are aimed at military or healthcare chaplains while others are more broadly oriented. The learning goals, required courses, and objectives in these MA programs, like those of the MDiv programs in chaplaincy, are variable.

Much as the course requirements in MDiv and MA programs suggest a lack of consensus about what chaplains need to know, the approaches to CPE also vary. About half of the schools require at least one unit of CPE. Some require two units, and one - the Institute for Pastoral Studies at Loyola-requires their students to complete four units of CPE. The Academy for Jewish Religion integrates units of CPE with graduate academic courses so that students participate in the experiential and interpersonal process of CPE while also engaging a 
more rigorous and structured syllabus of reading materials than a CPE unit usually requires. As Rochelle Robins explains, "Our program. .. combines one unit of CPE with six credits that are academic." Sometimes the work is structured around topics. For example, the topic of spiritual assessment might alternate between students' experiences with patients in their CPE units and broader and deeper readings on the topic in their academic work.

In addition to the MDiv and MA programs, about half of the schools in our sample offer additional chaplaincy training options. Five of the schools offer doctorates of ministry or PhDs with specific foci in chaplaincy, typically a DMin with a chaplaincy focus, although University of the West offers a doctor of Buddhist ministry degree and Claremont a doctor of philosophy in practical theology degree with a concentration in spiritual care and counseling. Six schools also offer courses in chaplaincy that lead to certificates independent of degrees. These programs serve community members, people who wish to explore chaplaincy as a vocation before enrolling in an MDiv, and others. They typically require 12 to 24 credit hours to complete.

The faculty members who designed the programs in our sample and who teach the courses and advise the students are as diverse as the programs they run. Two-thirds hold PhDs and others hold a DMin, EdD, or master's degree. Four are also certified as ACPE educators - a credential that arguably represents as many years of advanced training as a doctorate. Quite a few are pastoral theologians, but the range of academic disciplines to which others belong is wide, including education, ethics, healthcare planning, interdisciplinary studies, intercultural studies, Islamic studies, psychology, religious studies, and sociology. Some of the faculty members in the sample have been in academia their entire professional lives; others acquired their degrees during or subsequent to previous careers in military chaplaincy, counseling, or community organizing.

\section{The aims of theological education for chaplains}

In the interviews we conducted, the faculty who designed these programs, and who teach and mentor students in the programs, emphasized three broad areas they focus on in their teaching. First, they emphasized the importance of learning to work in a multifaith environment. Second, they emphasized learning that helps students think and reflect theologically and use that perspective to address suffering. And third, they spoke about the identity and authority of the chaplain both in a professional and in a personal context. The centrality of working in a multifaith context was the backdrop of all of these conversations. Shelly Rambo at Boston University directly stated that chaplains "need to be able to work in a multifaith setting," and Christopher Schelin at Starr King added that all chaplains need to "think theologically about how to deal with difference." All of the faculty agreed that chaplaincy is incompatible with proselytization.

How educators teach students to engage in this multifaith environment was nuanced differently from school to school. At evangelical schools, educators often began their discussion of religious diversity by describing the dilemma of the conservative evangelical seminarian who initially finds the idea of religious pluralism uncomfortable or even intolerable. Chaplaincy at evangelical schools framed the chaplain's universal caregiving as a silent form of witness to the Christian faith, a witness that waits patiently for the moment when another person invites the chaplain to share their faith in a way that renders the exchange ethical. Of 
her conservative evangelical students, McCormack said, "It isn't that they can't evangelize the way that they grew up if the person asks and the door is open, but that they don't necessarily have to do it that same way. They make it a dichotomy. Either I can't or I must. And I'm saying, it's always about the client. It's about their needs and their timing. It is not about you."

Evangelical chaplaincy faculty value knowledge about religious traditions other than Christianity, but their first educational task is sometimes to persuade students that chaplaincy requires a certain evangelical reserve. "You have to hear and receive and not be offended, and then to be able to love and to take care of and come alongside of," said Mike Langston. "When you do that, later on they're going to come back to you and they might start asking you those theological questions that you want to dive into right now. But it might be ten weeks. It might be a whole year before they ever get to that point." William Payne of Ashland framed this slightly differently as he explained how evangelical students can do this work while maintaining their own religious identities.

What we do in our classrooms is I make a distinction between being able to minister effectively in a pluralistic ministry environment and adopting a pluralistic theology. In other words, if you're evangelical, [you can] hold firmly to your evangelical faith and still be a successful chaplain if you're able to develop a theology that helps you minister in a pluralistic setting while embracing pluralism, the pluralistic context, without compromising your own faith identity.

At the interfaith schools, these concerns about plurality were muted. Faculty, instead, more directly addressed the importance of caring for persons with a wide range of religious, nonreligious, and spiritual perspectives. Jürgen Schwing of The Chaplaincy Institute pointed out that the program was founded "to enable students not just to serve people from diverse traditions but if they had a multireligious identity or an interspiritual or spiritual-but-notreligious identity." Duane Bidwell of Claremont noted that chaplains "need to be able to engage. .. people who have complex religious bonds. People. .. for whom spiritual fluidity, multiple religious belonging, are their expression of faith and practice."

In the Buddhist and Muslim degree programs, talk of the multifaith context took different forms because Jewish and Christian traditions remained a significant area of study and the faculty included scholars with substantial training and experience in those traditions. At University of the West, for example, the director of the chaplaincy program, Victor Gabriel, an ordained Tibetan Buddhist priest, is of Jewish and Asian ancestry, was raised Catholic, and was at a previous time in his life a Benedictine monk. Gabriel was recruited to University of the West specifically to teach the Abrahamic texts and traditions to Buddhist students, and he freely uses his understanding of one tradition to teach his students something about another. He uses the Bible and the Qur'an to introduce his students to the principles of hermeneutics before inviting them to bring a critical lens to the study of Buddhism, connects the Five Precepts to the philosophy of Martin Buber, and intentionally uses many of the same textbooks that his counterparts in Christian and Jewish schools would use. Gabriel says, "When I took over the program, we made it a rule that we would keep 50 percent what I call industry standards. That's how I market it to the students. Which, you know what it means, right? It means they are Christian. I told them that it's industry standards." As at Naropa, Bayan, and Hartford, the chaplaincy program at University of the West is focused on equipping students to navigate a landscape in which their own religious tradition, while it may represent a growing demographic in the United States, remains very much a minority. 
A third distinct emphasis in educating for multifaith work characterizes a group of schools that are linked not by religious tradition but by geography. Four schools - the United Methodist-affiliated Claremont, the ecumenical Buddhist University of the West, the transdenominational Academy for Jewish Religion, and Bayan, an Islamic graduate school established at Claremont - all have chaplaincy programs and offer cross-registration. At one point, this consortium of schools had funding to develop an interfaith chaplaincy program that would have truly been a joint venture. As originally imagined, the interfaith chaplaincy degree would have been an MA that was equivalent to an MDiv in terms of the number of credit hours and would have required students to develop an understanding of the doctrine, history, ethics, and practice in their own tradition but also to develop secondary expertise in another religious tradition. (In some ways, this is very similar to The Chaplaincy Institute's program, which requires students to know at least two traditions.) The funding for that degree program dissolved, but the schools have continued to cooperate to the best of their ability. As a result, students of all faiths have coursework available to them under the leadership of teachers of other faiths, and, depending on how the course schedule fits their needs, they may end up developing a deeper sense of another religious tradition in sideways fashion by studying something like counseling or ethics from another religious perspective.

In addition to talking about teaching students to work in multifaith contexts, educators frequently spoke about how theological education for chaplaincy teaches students to think and reflect theologically and use that perspective to address suffering. There was broad agreement that one of the central functions of a chaplain is to provide care for those in crisis. In the words of Jan McCormack at Denver "It's taking ministry to people.. .. But I'm so conscious of wanting to frame for chaplaincy in general and seeing that as such a viable, viable ministry that can take ministry to the people that are hurting and that are on the front lines of crisis." Educators emphasized that the great religious traditions of the world contain enormous wisdom for facing human suffering and that chaplains ought to know what that is. Laurie Garrett-Cobbina, the founder and director of the program at San Francisco, for example, described theological education as "a deep foundation in history or sacred texts, ethics, theological thought through the centuries." William Payne reiterated this point: "Graduate theological education trains students to be theologically fluent about using religious and theological approaches to suffering that come out of, you know, centuries-old religious traditions. .. to understand the problems of suffering that people are dealing with in their pastoral encounters." Mychal Springer of Jewish Theological Seminary offered that, especially when tempered by humility, depth in a religious tradition offers the freedom of knowing that the tradition itself is neither an answer key to life's mysteries nor dismissive of the search for answers. In her words,

When you have people with depth and humility, it gives permission to people who are searching to know that they are in good hands. One of the courses that we don't teach right now but we have taught is a pastoral theology course, and the students in the course received such comfort from knowing that their questions were all legitimate questions inside the tradition. That the tradition blesses questions and grappling. And when you study that from the inside, and you then meet people who are grappling with those questions on the outside, there's a way that you can then carry that mantle and bless their questions, not because you say, oh, nobody knows anything, but because you really know as a holder of the tradition that these are sacred, sacred questions and that the task 
of living and asking and wondering is a holy, ancient task that all people who have ever suffered have engaged in.

A majority of the educators also spoke about helping students learn to be theologically fluent, to use their theologies reflectively, and to apply them to their work with patients and families. This included faculty at schools across religious groups and historical paths. Dave Scheider at the Seminary of the Southwest described the theologians he teaches, explaining, "There has been so much work done on theological reflection methods.. .. I think as long as people are aware of these different ways of doing theological reflection. .. they can choose the one that fits the best." Scheider was clear, as were others, that the purpose of the reflection is to "work with the spirituality of the patient and not foist our spirituality onto them." Duane Bidwell framed this similarly, calling theological foundations a "resource for care." The aim, in his mind, is for students to clarify "the theological foundations and commitments of their own theology of care and how to embody their theology in action." It is these foundations then, that enable chaplains to work with patients. "I would argue that one of the ways spiritual care is distinct from behavioral health care or health care," Carrie Doehring explained, "is the ability to think critically about religious sources of authority, religious experiences, sacred texts, and in the midst of suffering when people are raising profound questions about suffering, they need someone that's going to help them think theologically."

Finally, educators were clear that education around the identity and authority of chaplains is central to what they teach in chaplaincy programs, including in formation. Some faculty emphasized chaplains' professional identities and the power they have in terms of what other people look to them to do. Garrett-Cobbina spoke about the transference and associations that attach to chaplains as soon as they introduce themselves as such. When the chaplain enters the room, she said, the patient responds out of whatever it is that the sacred or the holy represents to them. Rambo noted that the military chaplains in her program are often focused on getting further training in ethics because commanders place a high value on chaplains' ethical advice. Other faculty used metaphors about proximity to describe the chaplain's special identity and authority, describing the chaplain as the one who "comes alongside" or is good at "accompaniment." The founder of the program at Pentecostal, recently retired, titled his book on chaplaincy Outside the Gates, and Oliver McMahan, who directs the program now, emphasized the need for counseling skills and other practical ministry training to emphasize the extracongregational nature of chaplaincy. "A chaplain needs to be willing to go. .. outside the gates."

Embedded in these conversations were educators' perspectives about chaplains' personal identities. Duane Bidwell emphasized how important it is for students - as chaplains - "to know where they stand in relation to other religious traditions and where their boundaries are in terms of engaging those traditions." Dave Scheider at Seminary of the Southwest similarly emphasized the importance and difficulty of identity and authority, saying it is "one of the hardest things for many of us. .. how to be differentiated and have strong pastoral authority. .. and to value that we are different [and] that's why the system needs and wants us."

Presence, traditionally part of the way chaplains describe their identities and authorities, was also noted in several interviews (see also Adams 2019; Cadge 2018; Cash 2004; Jacobsen, 2012; Sullivan 2014). In the words of Victor Gabriel, "The chaplain brings the perspective of presence instead of doing.. .. But we try to say, step back, okay? There is this thing called ministry of presence. From that, the ministry of presence, I lead them to discover their own, not mine, but their own pastoral authority." In the words of M. Therese Lysaught at Loyola, "I do 
think that what they find is that mostly what they are is present to people in moments of crisis in a way that nobody else on the team is present to them. Their job is to be present. It's a spiritual sort of presence, sometimes it's a Christian presence, sometimes it's a Catholic presence, but fundamentally it's presence and accompaniment in a way that's not purveyed in, anywhere else on the healthcare team." Michael Langston of Columbia Biblical talks about chaplains as "bearers of the presence of God." In his words, "When the chaplain shows up, I talk about the chaplain being the bearer of the presence of God. .. there's just something happens when I know you're here. When I see you, I know that God's present.. .. And so I help them to understand that chaplaincy, when you walk in, you're bearing the presence of something." For some faculty, presence was fundamental to the chaplain's identity, whereas for others, it was just a starting point. Joretta Marshall of Brite called presence the bare minimum.

So, when I think about it, I appreciate the kind of whole theology of presence. . . . I think it's important, and way overdone. ... And when I teach [that], what I want them to think about is not just 'Am I showing up?' That's like 101, show up. And be a presence. But who do you think and what do you think you're doing when you enter that room? And it's not enough to just show up anymore, I don't think. . . . So I'm more interested in 'Can you articulate a question which invites people to sit for a moment and ponder rather than ask a question that has an answer?' Like, instead of saying, 'What church do you go to?,' to say, 'What does it mean that you go to your church?' or 'What does your church mean to you?"'

\section{Concluding and looking forward}

Attention to chaplaincy and spiritual care in theological education is growing, particularly since 2000. In addition to offering single classes, a quarter of the theological schools we identified have degree programs that address chaplaincy, and that number seems to still be on the rise. From MDiv programs to MA programs to a few DMin and $\mathrm{PhD}$ programs that focus on chaplaincy in the military, health care, or more broadly, chaplaincy seems to be one of few growth areas in theological education today. These programs are young and, as this review of their curricula reveals, quite varied. Neither theological educators nor the others involved in training chaplains - clinical educators or chaplaincy employers - have come to agreement about what well-trained chaplains need to know and where in their training - in theological school or clinical training - they should learn it. The religious organizations that support and in some cases credential chaplains and spiritual care providers also do not specify where in their training chaplains learn specific skills, how those skills connect to the daily work, and what the relationship is between skill building and formation or doing and being.

The unique contribution chaplaincy programs in theological education are making to the on-the-ground work of chaplains, in other words, remains unclear. Although we do not have information about the number of students enrolled in these programs or placements for graduates from these schools or others with chaplaincy programs, an unpublished review of 220 newly certified members of the Association for Professional Chaplains in 2017 showed that less than $15 \%$ completed chaplaincy-specific training in theological school. How individuals who complete chaplaincy-specific training in theological school compare in skills, placements, or other outcomes to those who complete theological degrees without such focus 
and go on to work as chaplains is an open question and one that is important to begin to answer.

The theological educators we interviewed see chaplaincy as a field continuing to grow even as they are aware, particularly in health care, of the financial uncertainty of the positions. Several imagine chaplains working in a broader range of settings in health care and beyond. "As people get less and less religious and denominational-based," one educator explained, "chaplaincy fits with the spirituality idea and it fits with the nondenominational idea." If spiritual care is going to be done, another reflected, "it is going to be done where people work" - an idea that potentially opens up a range of workplaces to chaplains. The ability to work in interfaith settings will remain central, most emphasize, though at least one educator worries that Christianity may "get pushed to the side" in that process and "prohibited from having a voice."

We agree with several of the educators who see the need to more closely align the varied people who train chaplains - theological and clinical educators - and to think carefully about what chaplains need to do their work well and how to train them for it. One educator expressed the desire to develop curricula more targeted to needed competencies in collaboration with working chaplains. "I wish, at least at our place," this educator reflected, "that there was an even tighter correlation between specific competencies that are informed by chaplains in the field.. .. I think a curriculum [should be] more reflective of those alliances, specifically the formation of program learning outcomes, behavioral performance outcomes." Some educators are uncomfortable with the language of competencies, preferring to talk about the balance between training chaplains to $b e$ and to $d o$. A few felt that the growing attention to evidencebased approaches to spiritual care raises questions about what role, if any, theological education has in preparing chaplains to do this work. As another educator explained,

I think there's this whole question now, if we buy $100 \%$ into an evidence-based approach to spiritual care, where does that put graduate theological education? And what is distinct about spiritual care? I would argue that one of the ways spiritual care is distinct from behavioral health care or health care in general is the ability to think critically about religious sources of authority, religious experiences, sacred texts, and in the midst of suffering when people are raising profound questions about suffering, they need someone that's going to help them think theologically. I think that's one of the big challenges right now, particularly in healthcare chaplaincy.

We believe the time is ripe for a national conversation about these issues, one that is not just focused on how to train and prepare chaplains but also aware and reflective of the demand side. Which organizations hire chaplains? What do these organizations need on the ground today from chaplains and spiritual caregivers? How can the educators rethink and align their training and approaches to meet the needs of the people spiritual caregivers serve? We suggest an approach to these conversations in another article (Cadge et al. 2019) and further suggest that key questions in this conversation include what individuals need to know to be good chaplains, which institutions help prepare them for that work, and how theological educators and clinical educators can work alongside one another in ongoing conversation and partnership. We see some models for such an approach in theological schools directly connected to $\mathrm{CPE}$ centers and encourage even broader national conversation among these sites to share best practices and help to standardize and professionalize the training of chaplains. These conversations must be enriched by including other professionals outside of theological circles, such as 
in mental health, disaster relief, and other fields, who care for the same people chaplains do with different sets of tools.

In addition to thinking about educational objectives and the institutional relationships between theological schools and CPE centers, we see the need for systematic attention to training the next generation of leaders (including faculty) in chaplaincy and spiritual care. Some of the founders of these programs are close to retirement and are the only people in their schools supporting chaplains, and there are not educators in the pipeline to replace them-and certainly not one that represents the diversity of the people chaplains serve across sectors. If, as the evidence suggests, more clergy are working outside of congregations and fewer people are affiliated with religious organizations, it is chaplains who may be the primary individuals in the public sphere equipped to provide spiritual care in times of crisis in hospitals, the military, and disaster relief zones or even during the routine existential issues that arise when moving through life.

Open Access This article is licensed under a Creative Commons Attribution 4.0 International License, which permits use, sharing, adaptation, distribution and reproduction in any medium or format, as long as you give appropriate credit to the original author(s) and the source, provide a link to the Creative Commons licence, and indicate if changes were made. The images or other third party material in this article are included in the article's Creative Commons licence, unless indicated otherwise in a credit line to the material. If material is not included in the article's Creative Commons licence and your intended use is not permitted by statutory regulation or exceeds the permitted use, you will need to obtain permission directly from the copyright holder. To view a copy of this licence, visit http://creativecommons.org/licenses/by/4.0/.

\section{References}

Adams, K. (2019). Defining and operationalizing chaplain presence: A review. Journal of Religion and Health, 58(4), 1246-1258.

Asquith Jr., G. H. (1992). Vision from a little known country: A Boisen reader. Decatur: Journal of Pastoral Care Publications.

Cadge, W. (2012). Paging god: Religion in the halls of medicine. Chicago: University of Chicago Press.

Cadge, W. (2018). God on the fly? The professional mandates of airport chaplains. Sociology of Religion, 78(4), $437-455$.

Cadge, W., Fitchett, G., Haythorn, T., Palmer, P., Rambo, S., Clevenger, C., \& Stroud, I. E. (2019). Training healthcare chaplains: Yesterday, today and tomorrow. Journal of Pastoral Care and Counseling., 73(4), 211-221.

Cash, C. H. (2004). A table in the presence. Nashville: W. Publishing Group.

Chang, P. M. Y. (2004). Assessing the clergy supply in the 21 st century. Pulpit \& Pew: Research on Pastoral Leadership.

Cooperman, A. (2015). America's changing religious landscape: Christians decline sharply as share of population; unaffiliated and other faiths continue to grow. Washington, DC: Pew Research Center.

Eastman, F. (1951). Father of the clinical pastoral movement. Journal of Pastoral Care, 5(1), 3-7.

Francis, L. J., Robbins, M., \& Wulff, K. M. (2013). Are clergy serving yoked congregations more vulnerable to burnout? A study among clergy serving in the Presbyterian church (USA). Stress and Health, 29(2), 113116.

Gerkin, C. V. (1997). An introduction to pastoral care. Nashville: Abingdon Press.

Hall, C. (1992). Head and heart: The story of the clinical pastoral education movement. Decatur: Journal of Pastoral Care Publications.

Holifield, E. B. (1983). A history of pastoral care in America: From salvation to self-realization. Nashville: Abingdon Press.

Jacobsen, D, \& Jacobsen, R. H. (2012). No longer invisible: Religion in university education. New York: Oxford University Press.

Jalalzai, S. (2016). Translating Islamic authority: Chaplaincy and Muslim leadership in north American Protestant seminaries. Unpublished doctoral dissertation. Columbia University, New York. 
Johnson, P. E. (1968). Fifty years of clinical pastoral education. Journal of Pastoral Care, 22(4), $223-231$.

Myers-Shirk, S. E. (2008). Helping the good shepherd: Pastoral counselors in a psychotherapeutic culture, 1925-1975. Baltimore: Johns Hopkins University Press.

Paget, N. K., \& McCormack, J. R. (2006). The work of the chaplain. Valley Forge: Judson Press.

Schleifer, C., \& Cadge, W. (2019). Clergy working outside of congregations, 1976-2016. Review of Religious Research., 61, 411-429.

Seager, R. H. (1999). Buddhism in America. New York: Columbia University Press.

Stahl, R. (2017). Enlisting faith: How the military chaplaincy shaped religion and state in modern America. Cambridge: Harvard University Press.

Sullivan, W. F. (2014). A ministry of presence: Chaplaincy, spiritual care and the law. Chicago: University of Chicago Press.

Tanner, T. (2017). Four trends that may portend the future for ATS enrollment: What the last decade says about the next decade. Journal of Christian Ministry, 6, 22-26.

Vaters, K. (2017, Dec. 12). The new normal: 9 realities and trends in bivocational ministry. Christianity Today. https:/www.christianitytoday.com/karl-vaters/2017/december/new-normal-9-realities-trends-bivocationalministry.html.

Wheeler, D. R. (2014, July 22). Higher calling, lower wages: The vanishing of the middle-class clergy. The Atlantic. https://www.theatlantic.com/business/archive/2014/07/higher-calling-lower-wages-the-collapse-ofthe-middle-class-clergy/374786/.

Publisher's Note Springer Nature remains neutral with regard to jurisdictional claims in published maps and institutional affiliations. 